Lepr Rev (1991) 62, 201-205

\title{
The protective effects of methyl cellulose and conoid shields for lagophthalmos and corneal hypaesthesia in leprosy
}

\author{
M A KARAÇORLU*†, T ÇAKINER††, Z SÜREL*, \\ $\mathrm{N}$ ERSOY $\dagger, \mathrm{T}$ SAYLAN $\dagger \&$ M SÜTLAS $\dagger$ \\ * Department of Ophthalmology, Cerrah passa School of Medicine, \\ University of Istanbul; and $\dagger \dot{I}_{\text {stanbul Leprosy Hospital and }}$ \\ Research Centre, Bakirköy, İstanbul, Turkey
}

\section{Accepted for publication 9 November 1990}

\begin{abstract}
Summary Lagophthalmos and corneal hypaesthesia are amongst the most frequently encountered lesions in leprosy and they can easily giverise to blindness. Many measures (such as eye drops, protective conoid shields, muscle exercises, surgical treatment etc.) have been used to protect the eyes under such circumstances and this paper examines the protective role of methyl cellulose and conoid shields in 41 patients. All of them had lagophthalmos ( $5 \mathrm{~mm}$ or more) and corneal hypaesthesia. They were divided into three groups. Group one had 15 leprosy control patients ( 27 eyes) who did not use methyl cellulose or eye shields. Group two had 16 leprosy patients ( 28 eyes) and they used methyl cellulose and eye shields when they felt discomfort in their eyes. Group three had 10 leprosy patients (17 eyes) and they used methyl cellulose and eye shields regularly. Statistically significant improvement was seen in group three. Further studies on larger groups of patients including the effects of different concentrations of methyl cellulose, on Schirmer test and tear break up time, may be of value.
\end{abstract}

\section{Introduction}

Leprosy is a chronic systemic infection caused by Mycobacterium leprae which frequently damages the eyes. ${ }^{1}$ According to the World Health Organization, leprosy blinds up to one million patients, yet ocular complications of the disease get little attention in programmes for the prevention of blindness. ${ }^{2}$ Some conditions are: a, impairment of facial and trigeminal nerve function, causing lagophthalmos with exposure of the corneal and conjunctival hypaesthesia; and $b$, bacillary invasion of the cornea, conjunctive, iris and ciliary body with consequent inflammatory reactions and such complications as loss of corneal transparency secondary glaucoma and cataract. ${ }^{3,4}$

We classified the lagophthalmos seen in leprosy into three groups: 1, paralytic lagophthalmos; 2, mechanical lagophthalmos; and 3, functional lagophthalmos.

$\ddagger$ Correspondence. 
Paralytic lagophthalmos can be found in patients throughout the spectrum. In the mechanical lagophthalmos of lepromatous leprosy (LL) cases there is damage and atrophy in the lid margin and this makes complete eye closure difficult. Following trigeminal or facial nerve pathology, functional lagophthalmos occurs. In some patients lagophthalmos may not be very obvious so that when asked to close their eyes, they are able to do so, however, because of some loss of corneal sensitivity, their blink reflex is very infrequent, we therefore refer to this condition as functional lagophthalmos.

In leprosy, there are various methods that can be used to protect and treat the problems that follow lagophthalmos. ${ }^{1,3}$ These methods have been investigated, but in patients given methyl cellulose solutions to protect the ocular surface, there have been no studies to assess effectiveness.

Although there are some disadvantages with the use of methyl cellulose, such as temporary blurred vision, initial burning sensations and most importantly, the mucin 'wash out' effect, there are significant advantages - it is cheap, easily prepared and has a long corneal contact time.

In this study, the protective effects of $1.5 \%$ methyl cellulose eye drops and conoid shields in the presence of lagophthalmos $(>5 \mathrm{~mm})$ and corneal hypaesthesia in ocular leprosy were investigated.

\section{Material and methods}

Of the 41 patients in our study, 26 were males and 15 were females, twenty-nine had lepromatous leprosy (LL), 9 had borderline lepromatous leprosy (BL) and 3 had borderline tuberculoid leprosy (BT).

The age of onset of leprosy was approximately the same and the average duration of the disease was $22 \cdot 7$ years (Table 1 ).

The 41 patients were divided into three groups. Group one had 15 control patients, representing 27 eyes with lagophthalmos, who did not use methyl cellulose and eye shields. Group two had 16 patients representing 28 eyes, methyl cellulose and eye shields were used when they felt discomfort in their eyes. Group three had 10 patients, representing 17 eyes, methyl cellulose and eye shields were used regularly 5-6 times a day. Group characteristics are summarized in Table 1.

Plastic conoid shields ${ }^{4}$ were produced from X-ray films by one of us (TÇ) and worn at night. These eye shields form a moisture chamber and also protect the eye from trauma. In

Table 1. Groups and their characteristics

\begin{tabular}{llccc}
\hline & & $\begin{array}{c}\text { No. of } \\
\text { eyes }\end{array}$ & $\begin{array}{c}\text { Ages } \\
\text { mean SD }\end{array}$ & $\begin{array}{c}\text { Disease } \\
\text { mean SD }\end{array}$ \\
\hline 1 & $\begin{array}{l}\text { Control (no treatment) } \\
2\end{array}$ & 27 & $47 \pm 11$ & $28 \pm 8$ \\
& $\begin{array}{l}\text { Self care MC* and S† used } \\
\text { when they felt discomf ort } \\
\text { Mandatory-supervised MC and S used regularly }\end{array}$ & 28 & $46 \pm 10$ & $21 \pm 9$ \\
& 17 & $48 \pm 8$ & $25 \pm 4$ \\
\hline
\end{tabular}

* Methyl cellulose.

$\dagger$ Protective eye shields. 
all eyes lagophthalmos, loss of corneal sensation, and corneal epithelial problems were present. Each group had been followed for one month and visual acuity and corneal epithelial fluorescein staining were recorded both before treatment and at the end of the follow-up period. Visual acuity was measured with the Snellen chart, and corneal staining was graded according to the scale shown in Table 2.

The Wilcoxon test was used for statistical assessment.

\section{Results}

In the first group, where methyl cellulose and shields were not used, there was no significant difference in corneal damage. In the second group, which used methyl cellulose and shields when discomfort was felt. Also there was no significant change in corneal staining. But in the third group, which used methyl cellulose and the shield at regular intervals throughout the day, there were significant improvements of the corneal epithelium at the end of the follow-up period (Table 3).

In testing for visual acuity before and after treatment, no statistically significant differences were found in any of the group (Table 4).

Table 2. Grading of corneal staining

\begin{tabular}{lc}
\hline & Grade \\
\hline No staining & 0 \\
$1 / 4$ of cornea is staining & 1 \\
$1 / 3$ of cornea is staining & 2 \\
$1 / 2$ of cornea is staining & 3 \\
Entire cornea stained in punctate fashion & 4 \\
\hline
\end{tabular}

Table 3. Changes in corneal damage before and after treatment

\begin{tabular}{|c|c|c|c|c|c|}
\hline \multicolumn{2}{|c|}{ Group 1} & \multicolumn{2}{|c|}{ Group 2} & \multicolumn{2}{|c|}{ Group 3} \\
\hline Before & After & Before & After & Before & After \\
\hline $1 \cdot 70 \pm 0 \cdot 92$ & $1 \cdot 85 \pm 0 \cdot 90$ & $2 \cdot 32 \pm 1 \cdot 19$ & $1 \cdot 14 \pm 1 \cdot 06$ & $1 \cdot 70 \pm 1 \cdot 04$ & $1 \cdot 05 \pm 0 \cdot 84$ \\
\hline \multicolumn{2}{|c|}{$\begin{array}{r}t=1.35 \\
P>0.05\end{array}$} & \multicolumn{2}{|c|}{$\begin{aligned} t & =1.99 \\
P & >0.05\end{aligned}$} & \multicolumn{2}{|c|}{$\begin{array}{c}t=2.10 \\
0.05<P<0.02\end{array}$} \\
\hline
\end{tabular}

Table 4. Changes in visual acuity before and after treatment assessed on a standard Snellen chart (decimalized)

\begin{tabular}{|c|c|c|c|c|c|}
\hline \multicolumn{2}{|c|}{ Group 1} & \multicolumn{2}{|c|}{ Group 2} & \multicolumn{2}{|c|}{ Group 3} \\
\hline Before & After & Before & After & Before & After \\
\hline $6 \cdot 96 \pm 2 \cdot 82$ & $7 \cdot 0 \pm 2 \cdot 79$ & $7 \cdot 60 \pm 3 \cdot 20$ & $7 \cdot 80 \pm 2 \cdot 89$ & $5 \cdot 40 \pm 2 \cdot 44$ & $6 \cdot 0 \pm 2 \cdot 59$ \\
\hline \multicolumn{2}{|c|}{$\begin{aligned} t & =0.61 \\
P & >0.05\end{aligned}$} & \multicolumn{2}{|c|}{$\begin{aligned} t & =0.53 \\
P & >0.05\end{aligned}$} & \multicolumn{2}{|c|}{$\begin{aligned} t & =1.29 \\
P & >0.05\end{aligned}$} \\
\hline
\end{tabular}




\section{Discussion}

The eyelids are an essential component of the protective mechanism of the eye. Each eyelid is built around a fibroelastic plate, the tarsus, on the posterior surface of which is the row of tarsal or meibomian glands, and the palpebral conjunctiva. The tarsal plates are attached to the orbital margin, nasally and laterally by the canthal tendons. Leprosy may cause premature atrophy of these structures contributing to a sagging lid margin. Many patients with severe paresis but retaining good sensation, will use Bell phenomenon in which the eye rolls up compensating for an inability to bring the lid down. ${ }^{3}$ Also, the pre-corneal tear film is essential to the metabolic needs of the cornea, to its normal functioning, and to its protection.

Disruption of the tear film by diminished lacrimal secretion, lid malposition or through the drying effect of diminished blinking can greatly impair corneal function. Most of the ocular problems in leprosy are caused by interference with the normal physiology of lid function and by the loss of the protective reflexes. ${ }^{3}$ The causes of ocular surface pathology in leprosy are summarized in Table 5.

As a result of this study, one can conclude that methyl cellulose and conoid shields may be of value in protecting the ocular surface epithelium of leprosy patients with lagophthalmos and impaired corneal sensation. But further investigations are needed, e.g. the effect of different concentrations of methyl cellulose on ocular surface epithelium, schirmer test and tear break-up time.

Table 5. The causes of ocular surface pathology in leprosy

$1 \quad$ Paralytic lagophthalmos

Increases the area of rima palpebrum: Evaporation increased

Corneal wetting reduced

Dry spots-exposure keratitis

2 Mechanical lagophthalmos

In all LL patients lepromatous damage occurs: lid glands tend to be destroyed and the sebum layer in the precorneal tear film reduced, evaporation increased

3 Hyposecretion of tear

Clofazimine (Lamprene) diminishes tear secretion, ${ }^{5}$ In LL cases, tear secretion reduced ${ }^{6}$

4 Hyposecretion of lysozyme and $\operatorname{Ig} A$

In lepromatous cases 6,7

\section{References}

1 Malaty R, Meyers WM, Walsh GP, Binford CH, Zimmerman LE, Baskin GB. Mangabey monkeys in lepromatous leprosy. Int J Lepr, 1988; 56: 443-8.

2 Brand MB, ffytche TJ. Eye complications in leprosy. In: Leprosy. Hastings RC, (ed.) Edinburgh, London, Melbourne, New York: Churchill-Livingstone, 1985; 223-42.

3 Joffrion VC, Brand MB. Leprosy of the eye a general outline. Lepr Rev, 1984; 55: 105-14.

4 Brand MB. Care of the eye in Hansen's disease. 2 nd ed. Carville LA. The Star, 1987; 1-25.

5 Negrel AD, Chovet M, Baquillon G, Lagadec R. Clofazimine and the eye: Preliminary communication. Lepr Rev, 1984; 55: 349-52.

${ }^{6}$ Hodges EJ, Ostler HB, Courtright P, Gelber RH. Keratoconjunctivitis sicca in leprosy. Lepr Rev, 1987; 58: 413-17.

7 Saha K, Sarin GS, Chakrabarty AK, Sen DK. Ocular immunoglobulins in lepromatous leprosy. Int J Lepr, 1977; 45: 338-41. 


\title{
Les éffets protectifs de la méthylcellulose et des écrans conoides pour la lagophthalmie et l'hipéstesie cornéene de la lèpre
}

\author{
M A Karacorlu, T Cakiner, Z Surel, N Ersoy, T Saylan et M Sutlas
}

Sommaire La lagophthalmie et l'hipéstesie cornéenne se trouvent entre les lésions lépreuses les plus courantes, et qui peuvent facilement produire la cécité. Beaucoup de mésures (gouttes pour les yeux, écrans conoides de protection, exercises musculaires, traitements chirurgicales, etc.) ont été utilisées pour protéger les yeux dans de telles conditions. Cet article examine le rôle protectif de la méthylcellulose et des écrans conoides chez 41 patients. Tous étaient atteints de lagophthalmie ( $5 \mathrm{~mm}$ ou plus) et d'hipéstesie cornéenne. Ils ont été séparés en trois groupes: le premier était formé par 15 patients de lèpre (27 yeux) comme groupe témoin qui n'ont pas utilisé ni la méthylcellulose ni des écrans conoides. Les 16 patients du deuxième groupe (28 yeux) ont utilisé la méthylcellulose et des écrans dés qu'ils sentaient malaise aux yeux. Le troisième groupe, avec 10 patients de lèpre (17 yeux) a utilisé la méthylcellulose et les écrans conoides régulièrement. Une amélioration statistiquement importante a été détectée dans le troisième groupe. Des études supplémentaires sur des groupes plus importants et qui pourraient comprendre les éff ets de concentrations différentes de méthylcellulose sur l'essai de Schirmer et le temps de désintégration des larmes, pourraient être utiles.

\section{Los ef ectos de la metilcelulosa y los escudos protectores conoideos como medidas de protección contra la lagoftalmía y la hipestesia corneal en la lepra}

\author{
M A Karacorlu, T Cakiner, Z Surel, N Ersoy, T Saylan y M Sutlas
}

Resumen La lagoftalmía y la hipestesia corneal son de las lesiones asociadas más frecuentemente con la lepra, y pueden fácilemente producir ceguera. Se han utilizado muchas medidas de protección para los ojos bajo tales condiciones (p.ej.colirios, escudos protectores conoideos, ejercicios musculares, tratamientos quirurgicos etc.). Este artículo examina la función protectora de la metilcelulosa y de los escudos conoideos en 41 pacientes. Todos padecían de lagoftalmía ( $5 \mathrm{~mm}$ o más) y de hipestesia corneal. Se dividieron en tres grupos. El primero, compuesto de un control de 15 pacientes de lepra ( 27 ojos) que no usaron ni escudos oculares ni metilcelulosa. El grupo número dos, 16 pacientes de lepra (28 ojos) que usaron metilcelulosa y escudos solo al sentir molestias en los ojos. El tercer grupo, de 10 pacientes de lepra (17 ojos), usó metilcelulosa y escudos de manera regular. Se observó una mejoría estadisticamente importante en los pacientes del tercer grupo. Estudios suplementarios sobre grupos mayores de pacientes que incluyan los ef ectos de diferentes concentraciones de metilcelulosa, sobre la prueba de Schirmer y el tiempo de desintegración de las lágrimas podrán resultar útiles. 